\title{
CONTRIBUTION TO THE KNOWLEDGE OF PLANT DIVERSITY AND HABITAT TYPES OF NON-FOREST VEGETATION IN THE SUBALPINE BELT OF MT TROGLAV AND ITS SURROUNDINGS (MT DINARA SENSU LATO)
}

\author{
Dario Hruševar* \& Božena Mitić \\ University of Zagreb, Faculty of Science, Department of Botany with the Botanical Garden, \\ Marulićev trg 9a, HR-10000 Zagreb, Croatia
}

Hruševar, D. \& Mitić, B.: Contribution to the knowledge of plant diversity and habitat types of non-forest vegetation in the subalpine belt of Mt Troglav and its surroundings (Mt Dinara sensu lato). Nat. Croat., Vol. 24, No. 1, 1-17, 2015, Zagreb.

Mt Troglav, the largest mountain of the Dinara massif, is located on the border area between Croatia and Bosnia and Herzegovina, with the highest peak Veliki Troglav on the Bosnian side. A short floristic observation of the non-forest habitats of the subalpine belt, with some vegetation remarks, was conducted during July, 2011. In total, 151 taxa from 48 families were recorded. The most abundant families are Poaceae $(9,9 \%)$, Asteraceae $(9,3 \%)$, Rosaceae $(8,6 \%)$ and Fabaceae $(7,9 \%)$. The most frequent life form is hemicryptophyta and the predominant chorological type is Euro-Asian. Eleven taxa are endemic. Five EU habitat types from Annex I of the Habitats Directive were analysed: 6170 Alpine and subalpine calcareous grasslands, 62A0 Eastern sub-Mediterranean dry grasslands (Scorzoneratalia villosae), 6230 *Species-rich Nardus grasslands, on siliceous substrates in mountain areas (and submountain areas in Continental Europe), 4070 *Bushes with Pinus mugo and Rhododendron hirsutum, 4060 Alpine and Boreal heaths. Also, some habitats that are not listed on the Habitats Directive, like the orders Atropetalia, Lamio albi-Chenopodietalia boni henrici and Adenostyletalia are shortly discussed. Those habitats on Mt Troglav are the result of human impact, which is today barely noticeable. Therefore, although the natural succession has been slow, seasonal grazing and mowing should be encouraged in those areas.

Key words: Bosnia and Herzegovina, Croatia, Dinara massif, ecological network, flora, habitats, Natura 2000, vegetation, Troglav Mountain

Hruševar, D. \& Mitić, B.: Prilog poznavanju biljne raznolikosti i nešumskih stanišnih tipova subalpskog pojasa Troglava i njegove okolice (masiv Dinare u širem smislu riječi). Nat. Croat., Vol. 24, No. 1, 1-17, 2015, Zagreb.

U graničnom području između Republike Hrvatske i Bosne i Hercegovine smjestio se Troglav, najveća i najviša planina središnjih Dinarida. Florističko istraživanje nešumskih staništa subalpinskog pojasa Troglava, s kratkim osvrtom na vegetaciju, provedeno je u srpnju 2011. g. Zabilježena je 151 svojta vaskularne flore razvrstana u 48 porodica. Značajnijim udjelom vrsta ističu se porodice: Poaceae $(9,9 \%)$, Asteraceae $(9,3 \%)$, Rosaceae $(8,6 \%)$, i Fabaceae $(7,6 \%)$. Analiza životnih oblika ukazuje na izrazitu dominaciju hemikriptofita, a fitogeografska analiza ukazuje na relativnu prevlast euroazijskog flornog elementa. Jedanaest je svojti endemično. U radu je analizirano pet stanišnih tipova s Dodatka I Direktive o zaštiti prirodnih staništa i divlje faune i flore: 6170 Planinski i pretplaninski vapnenački travnjaci, 62A0 Istočno submediteranski suhi travnjaci (Scorzoneretalia villosae), 6230 *Travnjaci tvrdače (Nardus) bogati vrstama, 4070 *Klekovina bora krivulja (Pinus mugo) s dlakavim pjenišnikom (Rhododendron hirsutum) i 4060 Planinske i borealne vrištine, ali i oni stanišni tipovi koji nisu uključeni u

* corresponding author: dario.hrusevar@biol.pmf.hr 
ekološku mrežu Europske unije Natura 2000, poput zajednica šumskih čistina (red Atropetalia), nitrofilna i skiofilna vegetacija (red Lamio albi-Chenopodietalia boni henrici) te pretplaninskih zajednica visokih zeleni (red Adenostyletalia). S obzirom da današnji izostanak ljudske djelatnosti na Troglavu omogućuje odvijanje prirodnih procesa sukcesije, bilo bi poželjno podržati ekstenzivno stočarenje u svrhu očuvanja biološke i krajobrazne raznolikosti.

Ključne riječi: Bosna i Hercegovina, Dinara, ekološka mreža, flora, Hrvatska, Natura 2000, staništa, Troglav, vegetacija

\section{INTRODUCTION}

The western part of the Central Dinarides is situated on the border area between Croatia and Bosnia and Herzegovina and is called Mt Dinara, sensu lato. Under this name the next set of mountains, called here the Dinara massif, can be recognized: Ilica, Dinara sensu stricto, Troglav, Prolog and sometimes Kamešnica. However, Mt Dinara, which is not the largest or the highest, gives the name to the whole chain of mountains that stretch from Italy to Albania, known as the Dinaric Alps or Dinarides. The highest peak of the Dinara massif and Mt Troglav, placed on the Bosnian side of the border, is Veliki Troglav, with an altitude of 1913m a.s.l. (PoljaK, 2007; Alegro \& Ruščić, 2010).

The Dinara massif is generally built of Jurassic and Cretaceous sedimentary, mainly carbonate rocks, so the karst formations in relief are quite frequent and the water bodies on the land surface are absent (PoLJAK, 2007). In the lower parts of the massif, a strong influence of the sub-Mediterranean climate can be perceived, but at the top of the massif, the climate is alpine. Mean annual precipitation is approximately $2000 \mathrm{~mm}$. Due to its vertical zonation, several vegetation belts can be distinguished, from the alliance OstryoCarpinion orientalis in the colline zone, through the alliance Aremonio-Fagion to the alliance Pinion mughi, at the highest altitude. Forest vegetation is mainly replaced by grasslands from the order Scorzoneretalia villosae in colline and montane zones and by the order Seslerietalia juncifoliae in altmontane and subalpine zones. On rocky places, sparsely vegetated habitats of the orders Potentilletalia caulescentis and Drypetalia spinosae are found (Anonymous, 2009; Alegro \& Ruščić, 2010).

On the Croatian side of the border, a larger area of the Dinara massif is a part of the Natura 2000 Network, an ecological network of the EU. Eight different habitat types are recognized in the mentioned area: 1) Temperate heath and scrub: 4060 Alpine and Boreal heaths and priority 4070 *Bushes with Pinus mugo and Rhododendron hirsutum, 2) Natural and semi-natural grassland formations: 6170 Alpine and subalpine calcareous grasslands, 6210* Semi-natural dry grasslands and scrubland facies on calcareous substrates (Festuco-Brometalia)(* important orchid sites), 62A0 Eastern sub-Mediterranean dry grasslands (Scorzoneratalia villosae), 3) Rocky habitats and caves: 8120 Calcareous and calcshist screes of the montane to alpine levels (Thlaspietea rotundifolii), 8210 Calcareous rocky slopes with chasmophytic vegetation, 8310 Caves not open to the public (AnONymous, 2013a).

The flora of the Dinara massif has been studied for the last 170 years. The first records are attributed to Visiani (1842-1852) who mentioned some findings of plants near Aržano and Prolog in his famous work "Flora Dalmatica". Till the end of the $19^{\text {th }}$ century he was followed by other botanists, such as Mazzolen, Roich, Maly (PolJAK, 2007), Pichler, Beck von Mannagetta and Protić (Volarić-Mršić, 1972). At the beginning of the $20^{\text {th }}$ century the same area was researched by Degen, Janchen, Watzl (PolJAK, 2007; Trinajstić \& ŠUGAR, 1972) and Handel-Mazzetti (FuKareK, 1959). Later, Ivo Horvat conducted several researches into the western Central Dinarides, especially on Mt Troglav (Horvat, 
1930-1931). He was followed by Fran Kušan and his research into Mt Kamešnica (KušAN, 1956). The issue about the distribution, chorological type and origin of plants in the Central Dinarides was discussed by Volarić-Mršıć (1976a,b). Because of the scarcity of recent data for Mt Troglav and its surroundings, the aim of this research was to contribute to the knowledge of its floristic diversity, with some remarks on vegetation.

\section{MATERIAL AND METHODS}

\section{Study area}

A floristic survey of non-forest habitats, such as grasslands and alpine heaths, excluding calcareous screes, covered the area of Male Poljanice, Veliki Troglav, Ledena gora, Vještića gora, Razdolje which are on the Bosnian side of the border, and Velike Torine and Klek which are partly on the Croatian side (Fig. 1). The mentioned toponyms are in general part of Mt Troglav. The altitude range was from around 1400 to $1913 \mathrm{~m}$ a.s.l. According to the Köppen climate classification, the area studied belongs to the snowforest climate with a cold summer (Dfc) (VolARIć-MršIć, 1972).

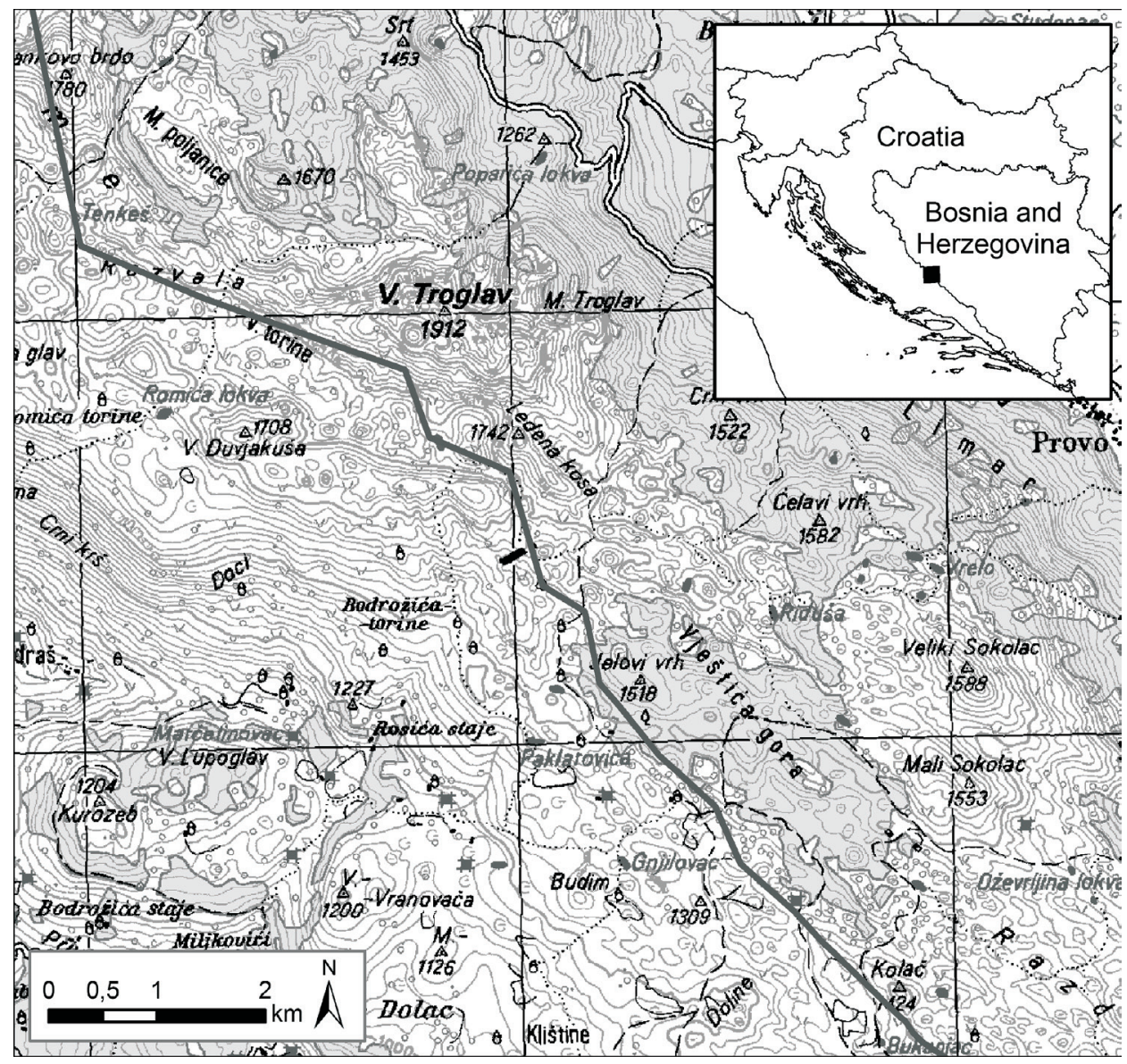

Fig. 1. Geographic position of the researched area. 


\section{Methods}

The flora of Mt Troglav and its surroundings was surveyed during July, 2011. For plant identification, standard determination keys were used: Tutin et al. (1968-1980, 1993), Javorka \& Csapody (1991), Martinčič et al. (1999), Domac (2002), Rothmaler (2007). For habitat identification the Croatian National Classification of Habitats (Anonymous, 2009) was used and then adjusted to the Habitat Directive according to the Interpretation Manual of European Union Habitats (ANONYmous, 2013b) in the way suggested by Topić \& VuKelić (2009).

Names of taxa, as well as their endemic status, were adjusted to the Flora Croatica Database (Nikolić, 2013). Plant families and genera with their appertaining species and subspecies are listed in alphabetical order within higher systematic units. In the list of taxa, each taxon is followed by life form (ElLENBERG et al. 1991), chorological type (Horvatić, 1963; Horvatić et al. 1967-1968; Simon et al. 1992; Pignatti, 2005) and conservation status, if any, at European (Bilz et al., 2011), Croatian (Anonymous, 2013c) and Bosnian levels (Anonymous, 2013d).

All plant taxa recorded for the first time in the flora of Mt Troglav are underlined. Endemic taxa are denoted with the sign ${ }^{\mathrm{x}}$ in front of the name of each taxon. Life forms are denoted by abbreviations: T - Therophytes; G - Geophytes; H - Hemicryptophytes; $\mathrm{Ch}-$ Chamaephytes and $\mathrm{P}$ - Phanerophytes. The abbreviations for chorological types are: IB - Illyrian-Balkan; SE - South-European, SEE - Southeast-European, CE - CentralEuropean, E - European, EA - Eurasian, CHA - Circumholarctic, subCos - (Sub)Cosmopolites. SEE also includes the East European-Pontic (EEP) chorological type, due to the low number of taxa in this category. Conservation status is estimated at the European, Croatian and Bosnian levels. In the first case, the prefix eu is used to distinguish their status from the Croatian Red List, denoted with prefix cro, and the Red List of the Federation of Bosnia and Hercegovina, denoted with prefix bih. From the Red List the next categories are present: CR - Critically Endangered, E - Endangered, VU - Vulnerable, NT - Near Threatened, LC - Least Concern and DD - Data Deficient. Natural habitat types of community interest whose conservation requires the designation of special areas of conservation are: 6170 Alpine and subalpine calcareous grasslands, 62A0 Eastern sub-Mediterranean dry grasslands (Scorzoneratalia villosae), 6230 *Species rich Nardus grasslands on siliceous substrates in mountain areas (and submontain areas in Continental Europe), 4070 *Bushes with Pinus mugo and Rhododendron hirsutum, 4060 Alpine and Boreal heaths. Some habitat types, not included in the EU ecological network Natura 2000, but analysed here as non-forest vegetation, are from the orders Atropetalia (Vlieger 1937), Lamio albi-Chenopodietalia boni henrici (Kopecký 1969) and Adenostyletalia (G. Br.-Bl. et J. Br.-Bl. 1931).

\section{RESULTS AND DISCUSSION}

During this short field observation 151 taxa of vascular plants from 48 families were recorded. From that number, 102 taxa were already noticed by Protić (1900), BEск voN Mannagetta (1903a, 1903b, 1906a, 1906b, 1906c, 1907, 1909, 1914, 1916a, 1916b, 1918, 1920, 1921-1922, 1923, 1927), Beck von Mannagetta \& Maly (1950) and Beck von MANNAGETTA et al. $(1967,1983)$. The floristic list cannot be considered final as fieldwork was not carried out through the whole vegetation season but only during the summer. Also, forest habitats and screes were not included in this research, and the vegetation of rocky slopes was included only when it was not clearly separated from the vegetation of subalpine calcareous grasslands. 


\section{LIST OF TAXA}

\section{PTERIDOPHYTA}

Dryopteridaceae

Dryopteris villarii (Bellardi) Woynar ex Schinz et Thell.; G; SE

Ophioglossaceae

Botrychium lunaria (L.) Sw.; G; subCos

Woodsiaceae

Athyrium filix-femina (L.) Roth; $\mathrm{H}$, subCos

Cystopteris fragilis (L.) Bernh.; $\mathrm{H}$, subCos

\section{SPERMATOPHYTA}

\section{CONIFEROPHYTINA}

Cupressaceae

Juniperus communis L. ssp. nana Syme; P; CHA

Pinaceae

Pinus mugo Turra; P; EA

\section{MAGNOLIOPHYTINA}

MAGNOLIOPSIDA

Aceraceae

Acer obtusatum Waldst. et Kit. ex Willd.; P; IB

Apiaceae

Bupleurum falcatum L. ssp. cernuum (Ten.) Arcang.; H; E

Heracleum sphondylium L.; H; EA

Laserpitium siler L.; H; SE

Pimpinella saxifraga agg.

\section{Asteraceae}

Achillea clavennae L.; H; SE; croNT, bihVU

Achillea millefolium agg.

Adenostyles alliariae (Gouan) A.Kern.; H; SE

Antennaria dioica (L.) Gaertn.; Ch; CHA

${ }^{\mathrm{x}}$ Carduus collinus Waldst. et Kit. ssp. cylindricus (Borbás) Soó; H

Carlina acaulis L. ssp. simplex (Wettst. et Kit.) Nyman; H; E

Centaurea jacea agg.

Centaurea triumfetti All.; $\mathrm{H}$; SE

Cirsium eriophorum (L.) Scop.; H; E

Leontopodium alpinum Cass.; $\mathrm{H}$; EA, bih VU

Leucanthemum adustum (Koch) Gremli; H; SE

Omalotheca sylvatica (L.) Sch.Bip. et F.W.Schultz; H; EA 
Senecio doronicum (L.) L.; H; SE

Solidago virgaurea L.; H; CHA

Berberidaceae

${ }^{\mathrm{x}}$ Berberis croatica Horvat; P; croNT, bihVU

Betulaceae

Betula pendula Roth; P; EA

Boraginaceae

Cerinthe glabra Mill.; H; SEE

Pulmonaria angustifolia L.; H; CE

Brassicaceae

Biscutella laevigata L.; H; SEE

Campanulaceae

Campanula cochlearifolia Lam.; H; SE; croVU, bihNT

Campanula glomerata L.; H; EA

Campanula witasekiana Vierh; H; SE

Edraianthus graminifolius (L.) A.DC.; Ch; SE

Phyteuma orbiculare L.; H; E; bihLC

\section{Caprifoliaceae}

${ }^{x}$ Lonicera borbasiana (Kuntze) Degen; P; bihEN

Caryophyllaceae

${ }^{x}$ Dianthus integer Vis.; H; croVU

${ }^{\mathrm{x}}$ Arenaria gracilis Waldst. et Kit.; Ch; bihLC

Cerastium arvense L. ssp. rigidum (Vitm.) Hegi; H; SEE

${ }^{\mathrm{x}}$ Cerastium grandiflorum Waldst. et Kit; $\mathrm{Ch}$; bihLC

Silene multicaulis Guss.; H; SE

Silene pusilla Waldst. et Kit.; H; SEE

xSilene sendtneri Boiss.; $\mathrm{H}$; bihLC

Stellaria graminea L.; H; EA

Chenopodiaceae

Chenopodium bonus-henricus L.; H; E; croNT

Cichoriaceae

Scorzonera purpurea L. ssp. rosea (Waldst.et Kit.) Nyman; H; SEE; croDD

Hieracium glabratum Hoppe ex Willd.; H; SEE

Hieracium pilosella L.; $\mathrm{H}$; EA

Hieracium villosum Jacq.; H; SEE

Hypochoeris maculata L., H; EA

Leontodon hispidus L.; H; E

Crepis mollis (Jacq.) Asch.; H; E; croDD 
Cistaceae

Helianthemum nummularium (L.) Mill. ssp. glabrum (Koch) Wilczek; Ch; E Helianthemum oelandicum (L.) DC. ssp. alpestre (Jacq.) Breistr.; Ch; SE

Clusiaceae

Hypericum perforatum L.; H; EA

Crassulaceae

Sedum hispanicum L.; T; SEE

Sedum ochroleucum Chaix; Ch; SE

Sedum sexangulare L.; Ch; E

Dipsacaceae

Scabiosa cinerea Lapeyr. ex Lam.; H; E

Scabiosa silenifolia Waldst. et Kit.; H; SE; bihLC

Ericaceae

Arctostaphylos uva-ursi (L.) Spreng.; Ch; CHA; euLC, croVU

Euphorbiaceae

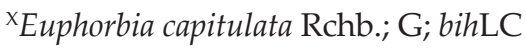

\section{Fabaceae}

Anthyllis montana L. ssp. jacquinii (A. Kern.) Hayek; Ch; SE

Anthyllis vulneraria L. ssp. alpestris (Kit. ex Schult) Asch. et Graebn.; H; E; bihLC

Coronilla vaginalis Lam.; Ch; E

Dorycnium spp.

Genista radiata (L.) Scop; Ch; SEE

Lathyrus spp.

${ }^{\mathrm{x}}$ Oxytropis dinarica (Murb.) Wettst.; $\mathrm{H}$; bihNT

Trifolium alpestre L.; H; EA; euLC

Trifolium montanum L.; H; EA

Trifolium pratense L. ssp. nivale (Koch) Arcang.; H; E; euLC

Trifolium repens L.; Ch; subCos; euLC

Chamaespartium sagittale (L.) Gibbs; Ch; CE

\section{Gentianaceae}

Gentiana lutea L. ssp. symphyandra (Murb.) Hayek; H; SEE; euLC, croNT; bihNT

Gentiana verna agg.

Gentianella crispata (Vis.) Holub; H; SEE; bihVU

Globulariaceae

Globularia cordifolia L.; Ch; E

Grossulariaceae

Ribes alpinum L.; P; EA

Lamiaceae

Betonica alopecuros L.; H; SE 
Lamium galeobdolon (L.) L.; H; EA

Micromeria thymifolia (Scop.) Fritsch; Ch; IB

Scutellaria alpina L.; G; E; bihNT

Stachys alpina L.; H; SE

Stachys recta agg.; bihCR

Teucrium montanum L.; Ch; E

Thymus praecox Opiz ssp. polytrichus (A.Kern. ex Borbás) Jalas; Ch; IB; bihNT

Thymus striatus Vahl; Ch; SEE

Linaceae

Linum capitatum Kit. ex Schultes; Ch; SEE; croNT

Onagraceae

Epilobium angustifolium L.; H; CHA

Plantaginaceae

Plantago holosteum Scop.; H; SEE

Plumbaginaceae

Armeria canescens (Host) Boiss. in DC.; H; SEE

Polygonaceae

Polygonum bistorta L.; G; CHA

Rumex acetosa L.; H; CHA

Primulaceae

Primula veris L. ssp. columnae (Ten.) Lüdi; H; SE; croNT

Ranunculaceae

Helleborus spp.

Thalictrum simplex L.; H; E

Rhamnaceae

Rhamnus alpinus L. ssp. fallax (Boiss.) Maire et Petitm.; P; SE

Rosaceae

Dryas octopetala L.; Ch; CHA; croDD, bihVU

Alchemilla plicatula Gand.; H; SE

Amelanchier ovalis Medik.; P; SEE

Cotoneaster integerrimus Medik.; P; EA

Cotoneaster nebrodensis (Guss.) C. Koch; P; SEE

Filipendula vulgaris Moench; $\mathrm{H}$; E

Fragaria viridis Duchesne; H; EA; euLC

Potentilla erecta (L.) Raeuschel; H; EA

Rosa pendulina L.; P; SE

Rubus idaeus L.; P; EA

Sorbus aria (L.) Crantz; P; E

Sorbus aucuparia L.; P; EA 
Sorbus chamaemespilus (L.) Crantz; P; E; bihVU

Rubiaceae

Asperula aristata L.f.; H; SEE

Cruciata glabra (L.) Ehrend.; H; EA

Galium lucidum agg.

Galium verum L.; H; EA

Salicaceae

Populus tremula L.; P; EA

Saxifragaceae

Saxifraga paniculata Mill. H; CHA

Scrophulariaceae

${ }^{x}$ Scrophularia bosniaca Beck H; euDD, croDD, bihEN

Euphrasia spp.

Pedicularis spp.

Pseudolysimachion barrelieri (Schott ex Roem. et Schult.) Holub; H; SEE

Rhinanthus aristatus Čelak; T; SE

Verbascum nigrum L.; G; EA

Veronica officinalis L.; Ch; CHA

Solanaceae

Atropa bella-donna L.; H; SE

Urticaceae

Urtica dioica L.; H; subCos; euLC;

Valerianaceae

Valeriana montana L.; H; SE

Violaceae

${ }^{x}$ Viola elegantula Schoot; H; croNT, bihLC

\section{LILIOPSIDA}

\section{Cyperaceae}

Carex hirta L.; G; EA

Carex kitaibeliana Degen ex Bech.; H; SEE

Juncaceae

Luzula campestris agg.

Liliaceae

Allium ericetorum Thore; G; E; euDD, bihEN

Allium sphaerocephalon L.; G; E; euLC

Allium victorialis L.; G; CHA; euLC

Polygonatum verticillatum (L.) All.; G; EA

Veratrum album L.; G; EA; croDD 
Poaceae

Agrostis capillaris L.; H; CHA

Anthoxanthum alpinum Á.Löve et D.Löve; H; EA

Brachypodium pinnatum (L.) P.Beauv.; H; EA

Bromus erectus Huds; $\mathrm{H}$; subCos

Calamagrostis varia (Schrad.) Host; H; EA

Dactylis glomerata L.; H; subCos

Deschampsia cespitosa (L.) P.Beauv.; H; subCos

Deschampsia flexuosa (L.) Trin.; H; subCos

Festuca bosniaca Kumm. et Sendtn.; H; IB; bihEN

Festuca paniculata (L.) Schinz et Thell.; H; SE; croDD

Festuca rubra agg.

Koeleria spp.

Nardus stricta L.; H; CHA

Sesleria robusta Schott, Nyman et Kotschy; H; IB

Sesleria tenuifolia Schrad.; H; SE

The most abundant families, with more than $5 \%$ of the total number of taxa, are Poaceae $(9.9 \%)$, Asteraceae $(9.3 \%)$, Rosaceae $(8.6 \%)$, Fabaceae $(7,9)$, Lamiaceae $(6.0 \%)$ and Caryophyllaceae (5.3\%). In the life form spectrum, hemicryptophyta are the most frequent $(62.8 \%)$, followed by chamaephyta (15.9\%) (Fig. 2). According to Horvat (1949), hemicryptophyta and chamaephyta are best adapted to cold conditions, so their high proportion was expected. Chorological analysis showed that the Eurasian geoelement is relatively dominant (22.1\%), followed by South-European (19.3\%) (Fig. 3). Endemic taxa are: Arenaria gracilis, Berberis croatica, Carduus collinus ssp. cylindricus, Cerastium grandiflorum, Dianthus integer, Euphorbia capitulata, Lonicera borbasiana, Oxytropis dinarica, Scrophularia bosniaca, Silene sendtneri and Viola elegantula.

There is quite a big difference in the number and level of threatened taxa between the European Red List of Vascular Plants (Bilz et al., 2011), the Croatian Red List (Anonymous, 2013c) and the Red List of Federation Bosnia and Herzegovina (Anonymous, 2013d). According to the first, none of the reported taxa are in Threatened categories. Nevertheless, the situation seems much worse at the regional, i.e. Croatian and Bosnian level. According to the Croatian Red List (Anonymous, 2013c) four taxa are under Threatened categories: Gentiana lutea ssp. symphyandra is Endangered and Arctostaphylos uva-ursi, Campanula cochlearifolia and Dianthus integer are Vulnerable. The Bosnian Red List (Anonymous, 2013d) recognises one Critically Endangered taxon - Stachys recta agg., four Endangered taxa - Allium ericetorum, Festuca bosniaca, Lonicera borbasiana, Scrophularia bosniaca and six Vulnerable taxa - Achillea clavennae, Berberis croatica, Dryas octopetala, Gentianella crispata, Leontopodium alpinum and Sorbus chamaemespilus. The final number of threatened taxa would be even higher if all of the observed plants were determined to the subspecies or variety level.

The most widespread Natura 2000 habitat type is 6170 Alpine and subalpine calcareous grasslands, which occupies the largest part of the researched area and according to the Croatian National Classification of Habitats (AnONymous, 2009), consists of two 


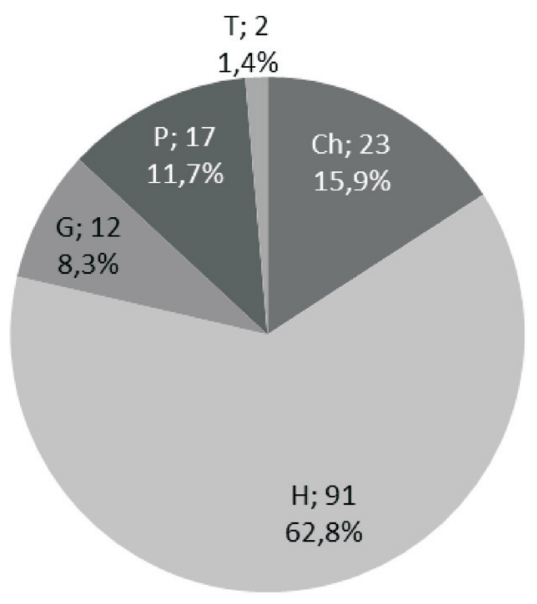

Fig. 2. Life forms spectrum.

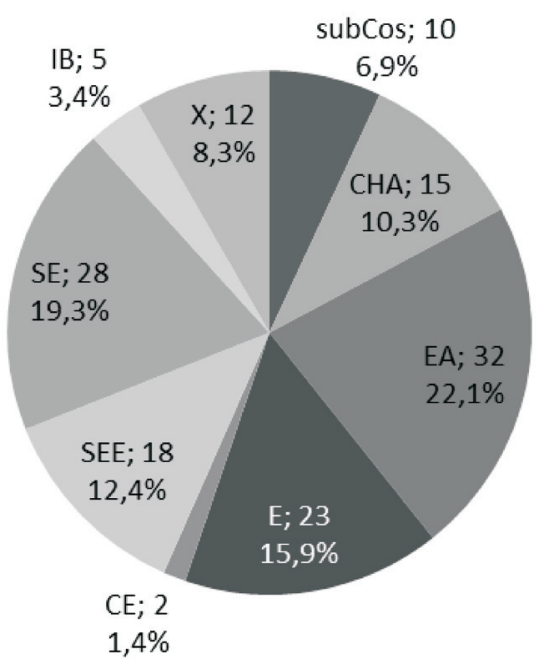

Fig. 3. Chorological spectrum same

alliances: Seslerion juncifoliae and Festucion bosniacae ("pungentis"). In Europe, this vegetation is mainly developed under the timberline, but in Croatia and Bosnia and Herzegovina scrubs with Pinus mugo do not exceed its upper limit on the Dinara massif, and grasslands are also developed at lower altitudes, in areas where locally climatic or pedological factors do not support wooden vegetation (HoRvat, 1930-1931). Furthermore, livestock activities were also of great importance for the development of grasslands (Mавкоvić, 2003). On this habitat type about one hundred plant species were found, including all endemic taxa, except Carduus collinus ssp. cylindricus, Lonicera borbasiana and Silene sendtneri. The life form spectrum of the 6170 habitat type shows the predominance of hemicryptophyta (64\%) which are followed by chamaephyta (22\%). These values are between those mentioned for the alliance Seslerion juncifoliae and Festucion bosniacae on the area of Dinarides (ŠALJA \& Redžıć, 2012). Chorological analyses show the dominance of the South European floral element (22\%). Calcareous grasslands are well developed over the whole of the researched area, with some domination of Sesleria tenuifolia, Sesleria robusta, Festuca bosniaca or Festuca paniculata (Fig. 4). Other quite frequent plants are: Scabiosa silenifolia, Phyteuma orbiculare, Gentiana lutea ssp. symphyandra, Senecio doronicum, etc. Species like Dryas octopetala and Leontopodium alpinum are quite rare in the investigated area.

In the studied area the species-rich Natura 2000 habitat type 62A0 Eastern sub-Mediterranean dry grasslands (Scorzoneratalia villosae) can rarely be found above $1500 \mathrm{~m}$. It is represented by the alliance Saturejon subspicatae where the endemic taxon Carduus collinus ssp. cylindricus was found. Other frequent species are: Armeria canescens, Plantago holosteum, etc.

On the researched area some patches of Nardus stricta were found, mainly on flattened surfaces, which is connected with the decalcification of the upper layer of calcareous soil. Some of these small acid grasslands belong to the Natura 2000 priority habitat type 6230 *Species-rich Nardus grasslands, on siliceous substrates in mountain areas (and 
submountain areas, in Continental Europe). Species found in these grasslands are: Nardus stricta, Luzula campestris agg., Antennaria dioica, Hypochoeris maculata, Veronica officinalis, Potentilla erecta, etc.

The EU priority habitat type 4070 *Bushes with Pinus mugo and Rhododendron hirsutum occurs toward or above the timberline, forming the scrub formation. The endemic species Lonicera borbasiana grows within this vegetation, but the characteristic taxon Rhodo-

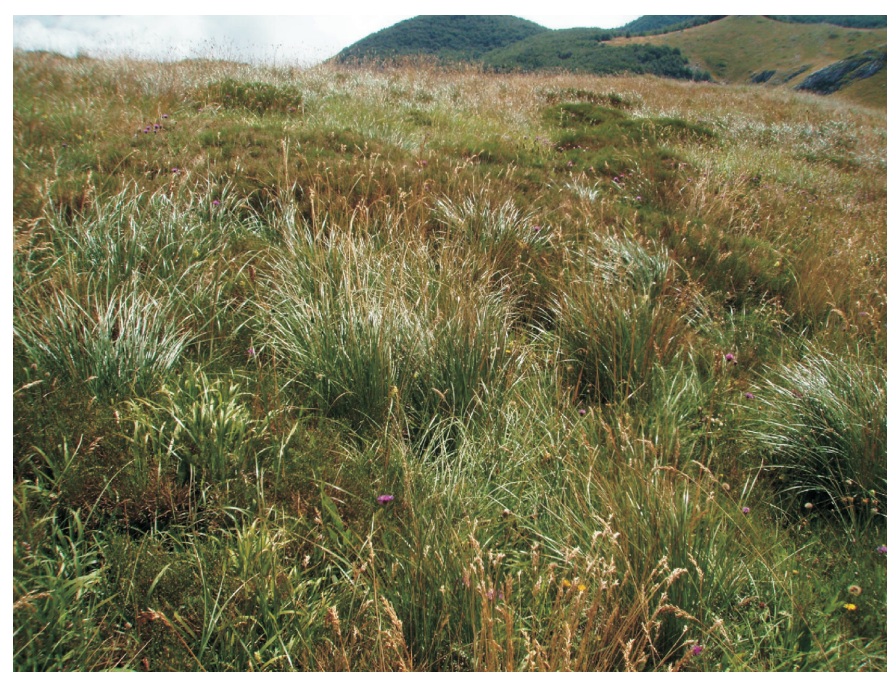

Fig. 4. Grassland dominated by Festuca paniculata (L.) Schinz et Thell., in the Jaram area. (photo: D. Hruševar)

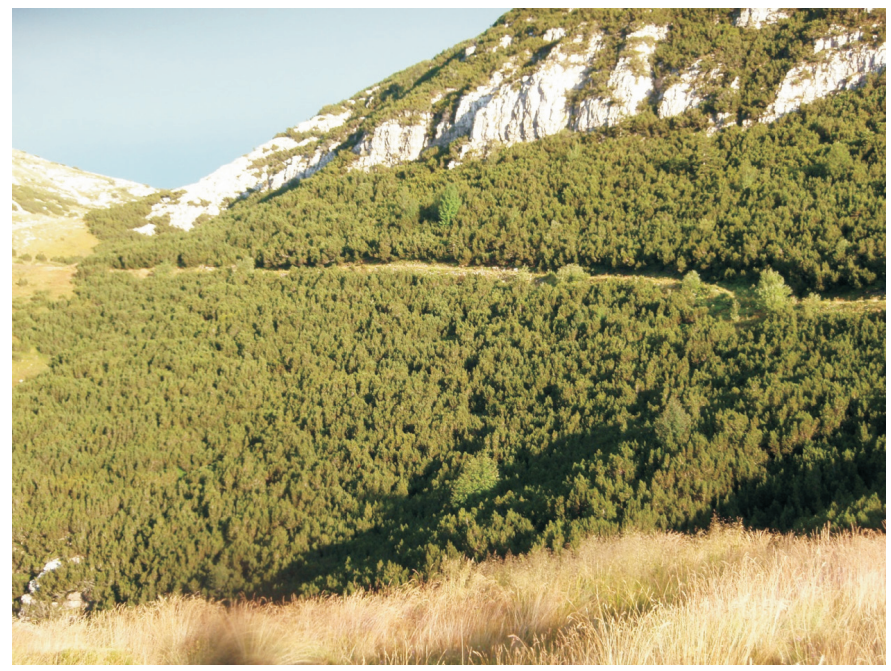

Fig. 5. Bushes with Pinus mugo Turra, in the cross-border Klek area. (photo: D. Hruševar) 


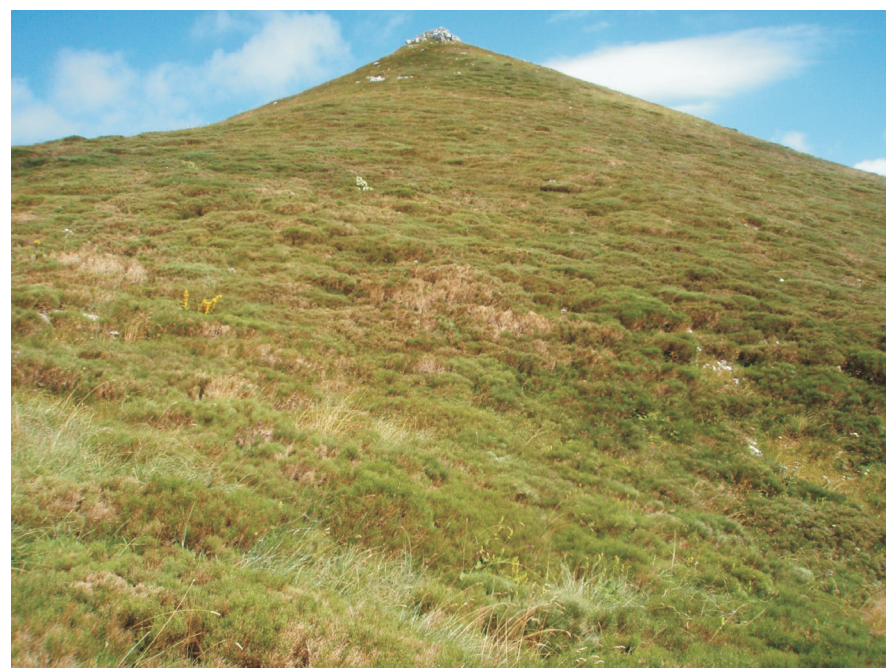

Fig. 6. Stands dominated by Genista radiata (L.) Scop., in the Jaram area. (photo: D. Hruševar)

dendron hirsutum L. was not found. According to Horvat (1930-1931) and FukAREK (1959) this habitat type was much more present in the past on the top belt of the whole Dinaric Alps, but was radically reduced by burning and cutting, as a result of human activity aimed at increasing the area of grasslands for grazing livestock. Having that in mind, it is easier to understand why this habitat type is today significantly present only in a small area, e.g. Klek near Rosića dolac (Fig. 5), Male Poljanice, Velike Torine and Veliki Troglav.

Quite often in the area where Pinus mugo is degraded, land is covered with stands dominated by Genista radiata (Fig. 6). This is quite typical for western Bosnian Mountains (FuKAREK, 1956). In the area studied the taxa Juniperus communis ssp. nana and Arctostaphylos uva-ursi also have important roles in succession. Such a kind of vegetation belongs to the Natura 2000 habitat type 4060 Alpine and Boreal heaths, which is well developed, especially on the Jaram area.

In places where beech forests were harvested the order Atropetalia is developed and presented with pioneer taxa, like Populus tremula and Betula pendula or includes small stands with the domination of Epilobium angustifolium. The order Adenostyletalia and Lamio albi-Chenopodietalia boni henrici is best presented in Rosića dolac, where large populations of Adenostyles alliariae and Chenopodium bonus-henricus were found. Also, quite often at the bottom of karst sinkholes, where the soil is deep and wet, the domination of grasses Deschampsia caespitosa and D. flexuosa was recognized, but the phytosociological status of this type of vegetation needs further research. Some taxa, like Polygonum bistorta and Silene sendtneri, were found only in this type of habitat.

\section{CONCLUSION}

In the largest area of the Central Dinarides the dominant type of vegetation are grasslands, and forests are reduced to small "islands". The reason for this breakdown of vegetation is the long-term human presence in this area, supported by specific geological and climatic characteristics. Burning, woodcutting and livestock rearing have signifi- 
cantly reduced the area of forest vegetation in the past and prevent the regeneration of the woodlands. Nevertheless, habitats influenced by humans in the studied area are recognized at the European level as important and those mentioned in this work are mainly a part of the Natura 2000 Network. On the other hand, today, when extensive livestock farming, as a form of low-intensive agricultural activity has been abandoned, the human impact is barely noticeable. This enables the smooth functioning of slow natural succession. However, to preserve the current state of nature, seasonal grazing and mowing, ordinary activities in the past on the researched area, should be encouraged.

Received December 18, 2013

\section{ACKNOWLEDGEMENTS}

The authors would like to thank our colleague Dr Igor Boršić for a providing map of the area researched and, also, to Dr Sandro Bogdanović and Dr Ivana Rešetnik for helping with literature sources.

\section{REFERENCES}

Alegro, A. \& Ruščić, M., 2010: Dinara. In: Nikolić, T., Topić, J. \& Vuković, N. (eds.), Botanički važna područja Hrvatske, Školska knjiga, Zagreb, 91-98.

Anonymous, 1992: Council Directive 92/43/EEC on the Conservation of natural habitats and of wild fauna and flora. The Council of the European Communities.

Anonymous, 2009: Pravilnik o izmjenama i dopunama Pravilnika o vrstama stanišnih tipova, karti staništa, ugroženim i rijetkim stanišnim tipovima te o mjerama za očuvanje stanišnih tipova. Narodne novine 119/09.

Anonymous, 2013a: Natura 2000 u Hrvatskoj. Državni zavod za zaštitu prirode. URL: http://natura2000. dzzp.hr/natura/[Accessed 20/09/2013].

Anonymous, 2013b: Interpretation Manual of European Union Habitats - EUR28. European Commission DG Environment.

Anonymous, 2013c: Crveni popis ugroženih biljaka i životinja Republike Hrvatske. Državni zavod za zaštitu prirode. URL: http://www.dzzp.hr/vrste/crveni-popis-biljaka-i-zivotinja-rh/ [Accessed 20/09/2013].

Anonymous, 2013d: Crvena lista flore Federacije Bosne i Hercegovine. Federalno ministarstvo okoliša i turizma. URL: www.fmoit.gov.ba [Accessed 20/12/2013].

Beck von Mannagetta, G., 1903a: Flora Bosne, Hercegovine i novopazarskog Sandžaka 1(1) - Gymnospermae i Monocotyledones. Glasnik Zemaljskog muzeja u Bosni i Hercegovini 15, 01-48.

Beck von Mannagetta, G., 1903b: Flora Bosne, Hercegovine i novopazarskog Sandžaka, 1(2) - Gymnospermae i Monocotyledones. Glasnik Zemaljskog muzeja u Bosni i Hercegovini 15, 185-230.

Beck von Mannagetta, G., 1906a: Flora Bosne, Hercegovine i novopazarskog Sandžaka 2(1). Glasnik Zemaljskog muzeja u Bosni i Hercegovini 18, 69-81.

Beck von Mannagetta, G., 1906b: Flora Bosne, Hercegovine i novopazarskog Sandžaka 2(2). Glasnik Zemaljskog muzeja u Bosni i Hercegovini 18, 137-150.

Beck von Mannagetta, G., 1906c: Flora Bosne, Hercegovine i novopazarskog Sandžaka 2(3). Glasnik Zemaljskog muzeja u Bosni i Hercegovini 18, 469-495.

Beck von Mannagetta, G., 1907: Flora Bosne, Hercegovine i novopazarskog Sandžaka 2(4). Glasnik Zemaljskog muzeja u Bosni i Hercegovini 19, 15-29.

Beck von Mannagetta, G., 1909: Flora Bosne, Hercegovine i novopazarskog Sandžaka 2(5). Glasnik Zemaljskog muzeja u Bosni i Hercegovini 21, 135-166.

Beck von Mannagetta, G., 1914: Flora Bosne, Hercegovine i novopazarskog Sandžaka 2(6). Glasnik Zemaljskog muzeja u Bosni i Hercegovini 26, 452-475.

Beck von Mannagetta, G., 1916a: Flora Bosne, Hercegovine i novopazarskog Sandžaka 2(7). Glasnik Zemaljskog muzeja u Bosni i Hercegovini 28, 41-168. 
Beck von Mannagetta, G., 1916b: Flora Bosne, Hercegovine i novopazarskog Sandžaka - Pteridophyta. Glasnik Zemaljskog muzeja u Bosni i Hercegovini 28, 311-336.

Beck von Mannagetta, G., 1918: Flora Bosne, Hercegovine i bivšeg Sandžaka Novog Pazara 2(8). Glasnik Zemaljskog muzeja u Bosni i Hercegovini 30, 177-218.

Beck von Mannagetta, G., 1920: Flora Bosne, Hercegovine i bivšeg Sandžaka Novog Pazara 2(9). Glasnik Zemaljskog muzeja u Bosni i Hercegovini 32, 83-128.

Beck von Mannagetta, G., 1921-1922: Flora Bosne, Hercegovine i bivšeg Sandžaka Novog Pazara 2(10). Glasnik Zemaljskog muzeja u Bosni i Hercegovini 33-34, 01-20.

Beck von Mannagetta, G., 1923: Flora Bosne, Hercegovine i bivšeg Sandžaka Novog Pazara 2(11). Glasnik Zemaljskog muzeja u Bosni i Hercegovini 35, 49-74.

Beck von Mannagetta, G., 1927: Flora Bosne i Hercegovine i oblasti Novog Pazara 3 - Horipetalae. Srpska kraljevska akademija. Beograd - Sarajevo.

Beck von Mannagetta, G. \& Maly, K., 1950: Flora Bosnae et Hercegovinae - Sympetalae 4(1). Biološki institut u Sarajevu. Sarajevo.

Beck von Mannagetta, G., Maly, K. \& BJelčić, Ž., 1967: Flora Bosnae et Hercegovinae - Sympetalae 4(2). Prirodnjačko odjeljenje Zemaljskog muzeja BiH u Sarajevu. Sarajevo.

Beck von Mannagetta, G., MaLy, K. \& BJelčić, Ž. 1974: Flora Bosnae et Hercegovinae - Sympetalae 4(3). Prirodnjačko odjeljenje Zemaljskog muzeja BiH u Sarajevu. Sarajevo.

Beck von Mannagetta, G., Maly, K., \& BJelčıć, Ž., 1983: Flora Bosnae et Hercegovinae - Sympetalae 4(4). Prirodnjačko odjeljenje Zemaljskog muzeja BiH u Sarajevu. Sarajevo.

Bilz, M., Kell, S.P., Maxted, N. \& Lansdown, R.V., 2011: European Red List of Vascular Plants. Publications Office of the European Union, Luxembourg.

DomAc, R., 2002: Flora Hrvatske - priručnik za određivanje bilja. Školska knjiga, Zagreb.

Ellenberg, H., Weber, H. E., Düll, R., Wirth, V., Werner,W. \& Paulissen, D., 1991: Zeigewerte von Pflanzen in Mitteleuropa, Scripta geobotanica 18, 1-248.

FUKAREK, P., 1956: Zajednica klekovine bora (Pinetum mughi Horvat) i neke njene razvojne tendencije na bosansko hercegovačkim planinama, Šumarski list 11-12, 343-357.

Fukarek, P., 1959: Planinski bor-klekovina (Pinus mugo Turra) i njegovo značenje za zaštitu tla i vegetacije naših planina, Naše starine 6, 203-218.

HoRvat, I., 1930-1931: Istraživanja vegetacije na Dinarskim planinama. Ljetopis Jugoslavenske akademije znanosti i umjetnosti 44, Zagreb.

HoRvat, I., 1949: Nauka o biljnim zajednicama. Nakladni zavod Hrvatske, Zagreb.

HoRvatić, S., 1963: Biljnogeografski položaj i raščlanjenje nešeg Primorja u svjetlu suvremenih fitocenoloških istraživanja. Acta Botan. Croat. 22, 27-81.

Horvatić, S., Ilijanić, Lj. \& Marković-Gospodarić, Lj., 1967-1968: Die Pflanzendecke der Umgebung von Senj. Senjski zbornik 3, 297-323.

KušAn, F., 1956: Sastav i raspored vegetacije na planini Kamešnici. God. Biol. inst. Univ. u Sarajevu 9, $3-26$.

JAVORKA, S. \& CsAPODY, V., 1991: Iconographia florae partis austro-orientalis Europae centralis. Akademia Kiado, Budapest.

Marković, M., 2003: Stočarska kretanja na Dinarskim planinama. Naklada Jesenski i Turk, Zagreb.

Martinčić, A., Wraber, T., Jogan, N., Ravnik, V., Podobnik, A., Turk, B. \& Vreš, B., 1999: Mala flora Slovenije - ključ za določanje praprotnic in semenk. Tehniška založba Slovenije, Ljubljana.

Niкоцı́́, T. (ed.), 2013: Flora Croatica Database. Department of Botany, Faculty of Science, University of Zagreb. URL: http://hirc.botanic.hr/fcd/[Accessed 11/09/2013].

PignatTi, S., 2005: Valori di bioindiccazione delle piante vascolari della flora d'Italia. Braun-Blanquetia 39, 1-97.

PoLJAK, Ž., 2007: Hrvatske planine $4^{\text {th }}$ ed. Golden marketing - Tehnička knjiga, Zagreb.

Protić, Đ., 1900: Prilog k poznavanju flore Bosne i Hercegovine. Glasnik Zemaljskog muzeja u Bosni i Hercegovini 12, 437-510.

RothmaLer, W., 2007: Exkursionflora von Deutschland 3 - Gefasaspflanzen: Atlasband. Elsevier GmbH, Munchen.

Simon, T., Horanszky, A., Dobloyi, K., Szerdahelyi, T. \& Horvath, F., 1992: Evaluation tables of Hungarian vascular flora. In: Simon, T. \& Magyarorszagi, A. (eds.), A magyarorszagiedenyes flora hatarozoja. Nemzeti Tankonyvkiado, Budapest. p. 837-955. 
ŠAlJA, E. \& ReDžıć, S., 2012: Ekološko-floristička diferencijacija planinskih rudina na karbonatima klase Elyno-Seslerietea Br-Bl. 1948. Akademija nauka i umjetnosti Bosne i Hercegovine, Posebna izdanja CXLVIII, Zbornik radova 22, 231-247.

Topić, J. \& Vukelić, J., 2009: Priručnik za određivanje kopnenih staništa u Hrvatskoj prema Direktivi o staništima EU. Državni zavod za zaštitu prirode, Zagreb.

TrinAJSTIĆ, I. \& ŠUgAR, I., 1972: Prilog poznavanju vegetacije suhih travnjaka na planini Dinari u Hrvatskoj. Acta Bot. Croat. 31, 165-171.

Tutin, T. G., Burges, N. A., Chater, A. O., Edmondson, J. R., Heywood, V. H., Moore, D. M., Valentine, D. H., Walters, S. M. \& Webb, D. A., 1993: Flora Europaea 1, 2nd ed. Cambridge University Press, Cambridge.

Tutin, T. G., Heywood, V. H., Burges, N. A., Moore, D. M., Valentine, D. H., Walters, S. M. \& Webb, D. A., 1968-1980: Flora Europaea 2-5. Cambridge University Press, Cambridge.

Visiani, R., 1842-1852: Flora Dalmatica. Lipsiae.

VolARIć-Mršıć, I., 1972: Rasprostranjenost i porijeklo flornih elemenata planinske vegetacije Dinarskih planina. Doktorska disertacija. Prirodoslovno-matematički fakultet Sveučilišta u Zagrebu, Zagreb.

VolArić-Mršıć, I., 1976a: Geoelement u planinskoj flori Dinare, Triglava i Kamešnice. Acta Bot. Croat. 35, 159-188.

VolARIĆ-Mršić, I., 1976b: Porijeklo i starost planinske flore Dinare, Troglava i KIamešnice. Acta Bot. Croat. 35, 189-203.

\title{
SAŽETAK
}

\section{Prilog poznavanju biljne raznolikosti i nešumskih stanišnih tipova subalpskog pojasa Troglava i njegove okolice (masiv Dinare u širem smislu riječi)}

\author{
D. Hruševar \& B. Mitić
}

Planina Troglav pruža se između Dinare i Kamešnice, u graničnom području između Republike Hrvatske i Bosne i Hercegovine, na čijem se teritoriju gotovo u cijelosti nalazi, a njezin vrh Veliki Troglav smatra se najvišim vrhom Dinarskog masiva. U ljeto 2011. godine provedeno je preliminarno florističko i vegetacijsko istraživanje nešumskih staništa subalpskog pojasa. Zabilježena je ukupno 151 svojta vaskularne flore razvrstane u 48 porodica. Brojem i udjelom svojti ističu se porodice Poaceae (15; 9,9\%), Asteraceae (14; 9,3\%), Rosaceae (13; 8,6\%) i Fabaceae (12; 7,9\%). Analiza životnih oblika ukazuje na izrazitu dominaciju hemikriptofita $(62.8 \%)$, a s udjelom većim od $10 \%$ slijede ih hamefiti i fanerofiti. Fitogeografska analiza ukazuje na relativnu prevlast euroazijskog (22,1\%) i južnoeuropskog (19,3\%) flornog elementa. Jedanaest je vrsta endemično: Arenaria gracilis, Berberis croatica, Carduus collinus ssp. cylindricus, Cerastium grandiflorum, Dianthus integer, Euphorbia capitulata, Lonicera borbasiana, Oxytropis dinarica, Scrophularia bosniaca, Silene sendtneri i Viola elegantula. Vegetacija je promatrana uglavnom na razini sveze te je potom usklađena, gdje je bilo moguće, s Direktivom o staništima EU. Ipak, neki stanišni tipovi, poput redova Atropetalia, Lamio albi-Chenopodietalia boni henrici te Adenostyletalia, koji nisu navedeni u Interpretacijskom priručniku stanišnih tipova Europske Unije, spomenuti su u radu jer predstavljaju nešumski oblik vegetacije prisutan na istraživanom području. Od Natura 2000 stanišnih tipova najveću površinu zauzimaju 6170 Planinski i pretplaninski vapnenački travnjaci na kojima su zabilježene 102 svojte, od toga 8 endemskih. 62A0 Istočno submediteranski suhi travnjaci (Scorzoneretalia villosae) tek u nepotpunom sastavu se pojavljuju u subalpskom pojasu. Prioritetni stanišni tip 6230 *Travnjaci tvrdače (Nardus) bogati vrstama razvijeni su na zaravnjenim površinama, na ispranom i zakiseljenom tlu, i ne zauzimaju velika područja. Prioritetna 4070 *Kleko- 
vina bora krivulja (Pinus mugo) s dlakavim pjenišnikom (Rhododendron hirsutum) u prošlosti je zauzimala daleko veće površine, ali je uslijed višestoljetnog kontinuiranog antropogenog pritiska značajno reducirana, međutim, lijepe sastojine još uvijek se nalaze podno Velikog Troglava, te na području Kleka, Malih Poljanica i Velikih Torina. Na područjima degradirane klekovine razvijen je stanišni tip 4060 Planinske i borealne vrištine, s dominacijom vrste Genista radiata. Šumske sastojine, koje danas zauzimaju samo male površine, kao i sipari, nisu bili obuhvaćeni istraživanjem. Čovjek, koji je svojom aktivnošću presudno utjecao na krajobraznu, vegetacijsku i florističku raznolikost istraživanog područja, ponekad s negativnim učinkom po prirodu, danas nije prisutan na Troglavu, što omogućuje sporo, ali kontinuirano odvijanje sukcesijskih procesa. Ipak, želimo li zadržati krajobraznu i biološku raznolikost, neophodno je poticati tradicionalnu nisko intenzivnu poljoprivrednu djelatnost, poput košnje $\mathrm{i}$ ispaše. 